\title{
Resistant Gene Analogous Marker Assisted Selection of Yellow Mosaic Virus Resistant Genotypes in Greengram (Vigna radiata)
}

\author{
M. Kabi ${ }^{1}$, T.R. Das ${ }^{2 *}$, B. Baisakh ${ }^{1}$ and D. Swain ${ }^{1}$ \\ ${ }^{1}$ Department of Plant Breeding and genetics, Orissa University of Agriculture and Technology, \\ Bhubaneswar- 751001, Odisha, India \\ ${ }^{2}$ Indian Agricultural Research Institute, Regional Station, Pusa, Bihar-848125, India \\ *Corresponding author
}

\section{A B S T R A C T}

\begin{tabular}{|l|}
\hline Ke y w o r d s \\
Greengram, \\
Molecular marker, \\
RGA, CYR1, \\
YMV. \\
\hline Article Info \\
\hline $\begin{array}{l}\text { Accepted: } \\
\text { 28 August } 2017 \\
\text { Available Online: } \\
\text { 10 September } 2017\end{array}$ \\
\hline
\end{tabular}

The molecular analysis of twenty six different greengram genotypes for YMV was carried out by using a resistant gene analogous (RGA) marker named CYR1 which produced amplicon at $90 \mathrm{bp}$ in seven genotypes (OBGG-2013-8, OBGG2013-21, OBGG-2013-16, OBGG-2013-11, OBGG-2013-20, OBGG-2013-39 and OBGG-2013-12) which concluded that these seven genotypes have yellow mosaic virus resistance gene and this marker is an efficient and ubiquitous for genotyping of YMV reaction. OBGG 2013-20 was an YMV resistance and high yielding line which can be used as YMV donor or can be released as a variety. OBGG 2013-34 have $23.88 \%$ higher yield potential than best check but moderately susceptible to YMD thus needs further improvement by hybridization with a suitable YMV resistant varieties.

\section{Introduction}

Mungbean or green gram, scientifically known as Vigna radiata L. Wilczek, is one of the important short duration pulse crops of India and an excellent source of good quality protein but the productivity is comparatively low i.e. $499 \mathrm{~kg} / \mathrm{ha}$ (Directorate of Economics and statistics, 2016). The major yield-limiting factors are various biotic (viruses, fungi, bacterial pathogens, and insects) and abiotic (salinity, drought, temperature, waterlogging, etc.) stresses. Among the biotic constraints, yellow mosaic disease (YMD) caused by the mungbean yellow mosaic virus is the major threat for huge economic losses in the Indian subcontinent (Nene, 1973).
The disease is caused by white fly (Bemicia tabaci) transmitted begomo gemini viruses with bipartite genomes (Varma and Malathi, 2003). Begomoviruses are a group of plant viruses containing single-stranded circular DNA encapsidated in geminate particles (Khattak et al., 2000; Karthikeyan et al., 2004). Greengram plants infected with YMD generally show yellowing or chlorosis of leaves followed by necrosis, shortening of internodes, and severe stunting of plants with no yield or few flowers and deformed pods produced with small, immature and shrivelled seeds (Akhtar et al., 2009). This disease causes 10-100 percent yield losses depending 
on the crop stage at which the plants being infected (Marimuthu et al., 1981; Bashir et al., 2006; Pandey et al., 2009).

The recent era of advanced biotechnology provides various molecular markers that can facilitate conventional breeding as marker assisted breeding (Ashraf and Foolad, 2013). Marker assisted indirect selection of resistant genotypes using linked markers has been reported as an effective breeding approach for developing yellow mosaic disease resistant cultivars. It is assuming increased importance due to lack of uniform field screening procedure as well as indirect selection due to complex virus vectors, host and environmental interaction (Souframanien and Gopalkrishna 2006).

Thus resistance genotype may be confirmed by molecular analysis and these resistance genotypes can be utilized in hybridization programme for transfer of resistance gene to the high yielding genotype susceptible to YMV for development of a high yielding YMV resistant varieties in a comparatively shorter time than conventional breeding.

Development of markers to identify YMV resistance in greengram and deploying them through marker-aided selection in breeding programme would fasten the process of developing resistant lines (Tanksley et al., 1989). Few molecular markers linked with disease resistance genes have been earlier reported for yellow mosaic virus in blackgram (Basak et al., 2004; Maiti et al., 2011, Sowami and Jayamani, 2014; Panigrahi et al., 2016). Use of RGA-markers is comparatively recent and can be conveniently designed from the diagnostic motifs of known disease resistance genes (Yan et al., 2003). Thus the present study was undertaken to link the available RGA markers with YMV resistance and identify the YMV resistant genotypes of greengram.

\section{Materials and Methods}

On the basis of YMV reaction under field condition, twenty six advance lines selected for molecular analysis (Table-1). The genomic DNA isolated from 5 - 20 days old seedlings of these genotypes by using standard CTAB (Cetyl Trimethyl Ammonium Bromide) method (Doyle and Doyle 1990). The quality as well as quantity of DNA was also checked by Uv-vis spectrophotometer (Jasco V 350, Japan). The absorbance at 260 $\mathrm{nm}$ wave lengths gave the quantity of the total DNA and the ratio of the absorbance at 260 and $280 \mathrm{~nm}$ indicated the quality of the purified DNA. The DNA was loaded in $2 \%$ agarose gel alongside diluted uncut lambda DNA as standard to recheck the quality and quantity and it was observed that the DNA from all the samples were qualitatively good.

The quantification was done in comparison with the known standard. After quantification, the DNA was diluted in $\mathrm{T}_{10} \mathrm{E}_{1}$ buffer to a working concentration of $25 \mathrm{ng} / \mu \mathrm{l}$ for $\mathrm{PCR}$ analysis. Amplification was carried out in 25 $\mu l$ reaction mixture contain $2 \mu 1$ primer (each forward and reverse), $0.5 \mu \mathrm{l} \mathrm{dNTP}, 0.5 \mu \mathrm{l}$ of 3 unit Taq DNA polymerase (Bangalore Genei, India), $2.5 \mu 1 \mathrm{Taq}$ buffer, $17.5 \mu 1 \mathrm{PCR}$ water and $2 \mu \mathrm{l}$ of DNA sample, using an AB system thermal cycler. The PCR cycle consisted of a denaturation step at $94^{\circ} \mathrm{C}$ for $300 \mathrm{~s}$, followed by 45 cycles of denaturation at $94^{\circ} \mathrm{C}$ for $60 \mathrm{~s}$ then further $60 \mathrm{~s}$ annealing at $60^{\circ} \mathrm{C}$ and extention at $72^{\circ} \mathrm{C}$ for 120 s followed by a final extension at $72^{\circ} \mathrm{C}$ of 720 s which is a slight modification as followed by Kalaria et al., (2014). The PCR- amplified products were separated in $1.5 \%$ agarose gel and visualized by ethidium bromide staining. The electrophoresis was performed at a constant voltage $(80 \mathrm{v})$ for 3 hours. Then these gels were placed on the Gel doc system (UVITECH, Cambridge, UK) and were photographed under U.V. light for scoring the 
bands. The sizes of the amplicons were determined by comparing them with that of the ladder banding pattern.

Disease score was recorded at maturity stage by counting number of infected plants in each line and the per cent disease incidence was calculated. The disease intensity was scored adopting the following 1-9 score (Singh et.al., 1988) (Table-1). On maturity 100 random plants of each entry selected and harvested separately from which the average plant yield of each entry calculated.

\section{Results and Discussion}

Twenty six genotypes of greengram with different genetic makeup with respect to YMV reactions were screened with PCRbased technique employing primer pairs to validate efficiency and reliability of identified marker loci. The molecular markers CYR1 showed amplifications at $90 \mathrm{bp}$ in seven genotypes with respect to disease reaction (Fig 1). The genotypes OBGG-2013-8, OBGG-2013-21, OBGG-2013-16, OBGG2013-11, OBGG-2013-20, OBGG-2013-39 and OBGG-2013-12 showed band in 3, 8, 9, $12,21,22$ and 24 well of the lane respectively indicating YMV resistance.

Average yield of the tested genotypes ranged from $1.40 \mathrm{~g} /$ plant to $5.55 \mathrm{~g} /$ plant (Table-3). It was observed that three lines i.e. OBGG 2013-34, OBGG 2013-20 and OBGG 201311 were superior than the best check (TARM1). However the best average seed yielding line (OBGG 2013-34) with an average yield of $5.55 \mathrm{~g} /$ plant was moderately susceptible to YMD thus needs further improvement by hybridization with a suitable YMV resistant variety. OBGG 2013-20 was YMV resistance ant high yielding (4.75 g/plant) line and can be used as YMV donor as well as can be released as variety after further yield improvement by proper plant selection.

Fig.1 Detection of PCR amplified with CYR1 marker linked with YMV resistance

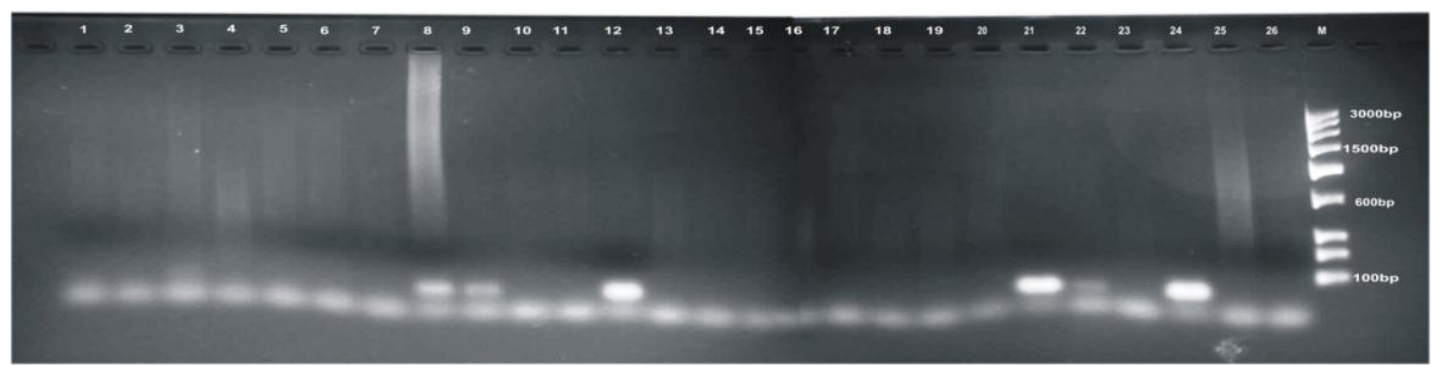

[Lane (1) OBGG-2013-41, (2) IPM 02-03, (3) OBGG-2013-8, (4) OUM 11-5, (5) TARM-1, (6) OBGG-2013-24, (7) OBGG-2013-7, (8) OBGG-2013-21, (9) OBGG-2013-16,(10) LGG 407, (11) LGG460, (12) OBGG-2013-11, (13) OBGG-2013-34, (14) OBGG-2013-2, (15) Dhauli, (16) OBGG-2013-14, (17) OBGG-2013-22, (18) OBGG-2013-5, (19) OBGG-2013-3, (20) OBGG-2013-15, (21) OBGG-2013-20, (22) OBGG-2013-39, (23) OBGG-2013-9, (24) OBGG-2013-12, (25) OBGG-2013-23, (26) Pusa9072, (M) 100bp molecular size marker]

Table.1 Rating scale for MYMV (Singh et al., 1988)

\begin{tabular}{|l|l|l|}
\hline Scale & Plants/foliage affected & Reaction \\
\hline 1 & $0.1-5.0 \%$ & Resistant (R) \\
\hline 3 & $5.1-10.0 \%$ & Moderately Resistant (MR) \\
\hline 5 & $10.1-25.0 \%$ & Moderately susceptible (MS) \\
\hline 7 & $25.1-50.0 \%$ & Susceptible (S) \\
\hline 9 & $50.1-100 \%$ & Highly susceptible (HS) \\
\hline
\end{tabular}


Table.2 Characters of RGA primers

\begin{tabular}{|l|l|l|c|c|l|}
\hline Primers & \multicolumn{1}{|c|}{ Primer sequences $\left(\mathbf{5}^{\prime} \mathbf{- 3}^{\prime} \mathbf{)}\right.$} & $\begin{array}{l}\text { \% } \\
\text { GC }\end{array}$ & $\begin{array}{c}\text { Annealing } \\
\text { temp. }\end{array}$ & $\begin{array}{l}\text { Expected } \\
\text { product }\end{array}$ & Reference \\
\hline RGA22F2 & GGGTGGTTTGGGTAAGACCAC & 57.1 & 60 & 90 & Maiti et al., 2011 \\
\hline RGA24R2 & TTCGCGGTGTGTGAAAAGTCT & 47.6 & 58 & 90 & Maiti et al., 2011 \\
\hline
\end{tabular}

Table.3 Reaction of greengram genotypes to YMD and their seed yield

\begin{tabular}{|c|c|c|c|c|c|}
\hline $\begin{array}{l}\text { Lane } \\
\text { No. }\end{array}$ & Entry & $\begin{array}{l}\text { RGA Marker } \\
\text { (CYR1) status }\end{array}$ & $\begin{array}{l}\text { Disease } \\
\text { Score }\end{array}$ & $\begin{array}{l}\text { Disease } \\
\text { Reaction }\end{array}$ & $\begin{array}{l}\text { Av. seed } \\
\text { yield }(g) \text { / plant }\end{array}$ \\
\hline 1 & OBGG-2013-42 & $\mathrm{A}$ & 7 & $\mathrm{~S}$ & 4.02 \\
\hline 2 & IPM 02-03 (C) & $\mathrm{A}$ & 7 & $\mathrm{~S}$ & 2.86 \\
\hline 3 & OBGG-2013-8 & $\mathrm{P}$ & 3 & MR & 3.83 \\
\hline 4 & OUM 11-5 (C) & $\mathrm{A}$ & 7 & $\mathrm{~S}$ & 2.75 \\
\hline 5 & TARM-1 (C) & $\mathrm{A}$ & 5 & $\mathrm{MS}$ & 4.48 \\
\hline 6 & OBGG-2013-24 & $\mathrm{A}$ & 7 & $\mathrm{~S}$ & 4.36 \\
\hline 7 & OBGG-2013-7 & $\mathrm{A}$ & 9 & HS & 4.15 \\
\hline 8 & OBGG-2013-21 & $\mathrm{P}$ & 1 & $\mathrm{R}$ & 3.45 \\
\hline 9 & OBGG-2013-16 & $\mathrm{P}$ & 1 & $\mathrm{R}$ & 3.89 \\
\hline 10 & LGG-407 (C) & A & 5 & MS & 1.86 \\
\hline 11 & LGG-460 (C) & $\mathrm{A}$ & 7 & $\mathrm{~S}$ & 3.49 \\
\hline 12 & OBGG-2013-11 & $\mathrm{P}$ & 3 & MR & 4.54 \\
\hline 13 & OBGG-2013-34 & $\mathrm{A}$ & 5 & MS & 5.55 \\
\hline 14 & OBGG-2013-2 & $\mathrm{A}$ & 5 & MS & 2.73 \\
\hline 15 & Dhauli (C) & $\mathrm{A}$ & 7 & $\mathrm{~S}$ & 1.65 \\
\hline 16 & OBGG-2013-14 & $\mathrm{A}$ & 5 & $\mathrm{MS}$ & 2.09 \\
\hline 17 & OBGG-2013-22 & $\mathrm{A}$ & 7 & $\mathrm{~S}$ & 2.22 \\
\hline 18 & OBGG-2013-5 & A & 9 & HS & 1.40 \\
\hline 19 & OBGG-2013-3 & $\mathrm{A}$ & 9 & $\mathrm{HS}$ & 2.10 \\
\hline 20 & OBGG-2013-15 & $\mathrm{A}$ & 9 & $\mathrm{HS}$ & 4.37 \\
\hline 21 & OBGG-2013-20 & $\mathrm{P}$ & 1 & $\mathrm{R}$ & 4.75 \\
\hline 22 & OBGG-2013-39 & $\mathrm{P}$ & 3 & MR & 2.77 \\
\hline 23 & OBGG-2013-9 & $\mathrm{A}$ & 5 & $\mathrm{MS}$ & 2.07 \\
\hline 24 & OBGG-2013-12 & $\mathrm{P}$ & 3 & MR & 3.56 \\
\hline 25 & OBGG-2013-23 & $\mathrm{A}$ & 9 & $\mathrm{HS}$ & 2.94 \\
\hline 26 & Pusa-9072 (C) & $\mathrm{A}$ & 5 & MS & 3.41 \\
\hline
\end{tabular}

(C) $=$ Released varieties used as checks

In conclusion, The RGA marker validated in this study, endowed with features of resistance gene candidate may be useful for generating superior genotypes with durable YMV resistance. The marker will be of use in marker assisted selection and will hopefully aid in the development of resistant cultivars in relatively shorter time span. Advantage of RGA markers are that these markers are completely linked with YMV resistance and these would assist in identifying plants endowed with resistance locus conferring 
YMV resistance straight away without challenging the plants with the pathogen for phenotyping, giving plant breeders the advantage to carry out repeated genotyping throughout the growing season in absence of any disease incidence. Additionally, screening of germplasms for virus resistance is possible directly from the seed stock. Identification of a linked marker with the desired trait is an essential requirement for Marker Assisted Selection (MAS) in advance breeding programme. Validation of marker by efficient screening is the process of unambiguous association of marker with the trait of interest. The YMV resistance lines (OBGG-2013-8, OBGG-2013-12， OBGG-2013-39， OBGG2013-21, OBGG-2013-16, OBGG-2013-11, OBGG-2013-20) confirmed by field and laboratory studies will be useful for donor in future breeding process. Genotype OBGG 2013-20 can be released as a high yielding YMV resistance line for southern zone of India or can be used as a source of parent for YMV resistance.

\section{References}

Akhtar, K.P., Kitsanachandee, R., Srinives, P., Abbas, G., Asghar, M.J., Shah, T.M., Atta, B.M., Chatchawankanphanich, O., Sarwar, G., Ahmad, M. and Sarwar, N. 2009. Field evaluation of mungbean recombinant inbred lines against mungbean yellow mosaic disease using new disease scale in Thailand. Plant Pathol. J., 25: 422428.

Ashraf, M. and Foolad, M. 2013. Crop breeding for salt tolerance in the era of molecular markers and marker-assisted selection. Plant Breed, 132: 10-20.

Basak, J., Kundagrami, S., Ghose, T.K. and Pal, A. 2004. Development Of Yellow Mosaic Virus (YMV) Resistance Linked DNA Marker In Vigna mungo From Populations Segregating For
YMV-Reaction, Molecular Breeding, 14: 375-383.

Bashir, M., Jamali, A.R. and Ahmed. Z. 2006. Genetic resistance in mungbean and mashbean germplasm against mungbean yellow mosaic begomovirus. Mycopath, 4(2): $1-4$.

Directorate of Economics and statistics (DES), 2016. // eands.dacnet.nic.in

Doyle, J.J., and Doyle, J.L. 1990. A rapid total DNA preparation procedure for fresh plant tissue. Focus, 12:13-15.

Kalaria, R. K., Digvijay, C., Kumar, M. and Mahatma, L. 2014. Identification of RAPD and ISSR makers for resistance against Mungbean Yellow Mosaic Virus in mungbean (Vigna Radiata L.) under south gujarat agro climatic condition of India. The Bioscan, 9(3): 1177-1182.

Karthikeyan, A.S., Vanitharani, R., Balaji, V., Anuradha, S., Thillaichidambaram, P., Shivaprasad, P.V., Parameswari, C., Balamani, V., Saminathan, M. and Veluthambi, K. 2004. Analysis of an isolate of mungbean yellow mosaic virus (MYMV) with a highly variable DNA B component. Arch Virol, 149: 1643-1652.

Khattak, G.S.S., Haq, M.A., Ashraf, M., Elahi, T. 2000. Genetics of mungbean yellow mosaic virus (MYMV) in mungbean (Vigna radiata (L.) Wilczek). J Genet Breed, 54: 237-243.

Maiti, S., Basak J, Kundagrami S, Kundu A, Pal A. 2011. Molecular marker-assisted genotyping of mungbean yellow mosaic India virus resistant germplasms of mungbean and urdbean, Mol Biotechnol, 47:95-104.

Marimuthu, T., Subramanian, C.L., Mohan, R. 1981. Assessment of yield losses due to yellow mosaic infection in mungbean. Pulse Crop News Letter, 1: 104.

Nene, Y.L., 1973. Viral diseases of some warm weather pulse crops in India. 
Plant Dis Rep., 57: 463-467.

Pandey, S., Sharma, M., Kumari, S., Gaur, P.M, Chen, W., Kaur, L., Macleod, W., Basandrai, A.K., Basandrai, D., Bakr, A., Sandhu, J.S., Tripathi, H.S. and Gowda, C.L.L. 2009. Integrated foliar diseases management of legumes. In: Grain Legumes: Genetic improvement, Management and Trade, Eds. By Masood Ali et al., pp.143-161. Indian Society of Pulses Research and Development, Indian Institute of Pulses Research, Kanpur, India.

Panigrahi, K. K., Das, T. R., Baisakh, B., Mohanty, A. and Pradhan, J. 2016 Validation of CYR-1 marker linked with yellow mosaic virus resistance in black gram (Vigna mungo L. Hepper) Indian J. Genet., 76(1): 104-106

Singh, G., Kapoor, S. and Singh, K. 1988. Multiple disease resistance in mungbean with special emphasis on mungbean yellow mosaic virus. In $S$. shanmugasundran (ed.) Proc. Second International mungbean symposium, 1620 Nov.1987, Bangkok. pp. 290-296.
Souframanien, J., and Gopalakrishna, T. 2006. ISSR and SCAR markers linked to the mungbean yellow mosaic virus (MYMV) resistance gene in blackgram [Vigna mungo(L.) Hepper]. Plant Breeding, 125(6): 619-622.

Sowmini, K., Jayamani P. 2014. Validation of molecular markers linked with yellow mosaic disease resistance in blackgram Vigna mungo L. hepper, Legume Genomics and Genetics, 5(4): 25-30.

Tanksley, S.D., Young, N.D., Paterson, A.H. and Bonierable, M.D. 1989. RFLP mapping in plant breeding: new tools for old science. Bio Technol., 7: 257264.

Varma, A., and Malathi, V.G. 2003. Emerging Gemini virus problems: a serious threat to crop production. Annals of Appl. Biol., 142: 145-164.

Yan, G.P., Chen X.M., Line R.F. and Wellings C.R. 2003. Resistance-gene analog polymorphism markers cosegregating with the Yr5 gene for resistance to wheat stripe rust. Theor. Appl. Genet. 106: 636-643

\section{How to cite this article:}

Kabi, M., T.R. Das, B. Baisakh and Swain, D. 2017. Resistant Gene Analogous Marker Assisted Selection of Yellow Mosaic Virus Resistant Genotypes in Greengram (Vigna radiata). Int.J.Curr.Microbiol.App.Sci. 6(9): 3247-3252. doi: https://doi.org/10.20546/ijcmas.2017.609.399 